\title{
EKG 4-2013: Ritmo sinusal+Eje QRS en situación Anteroposterior.
}
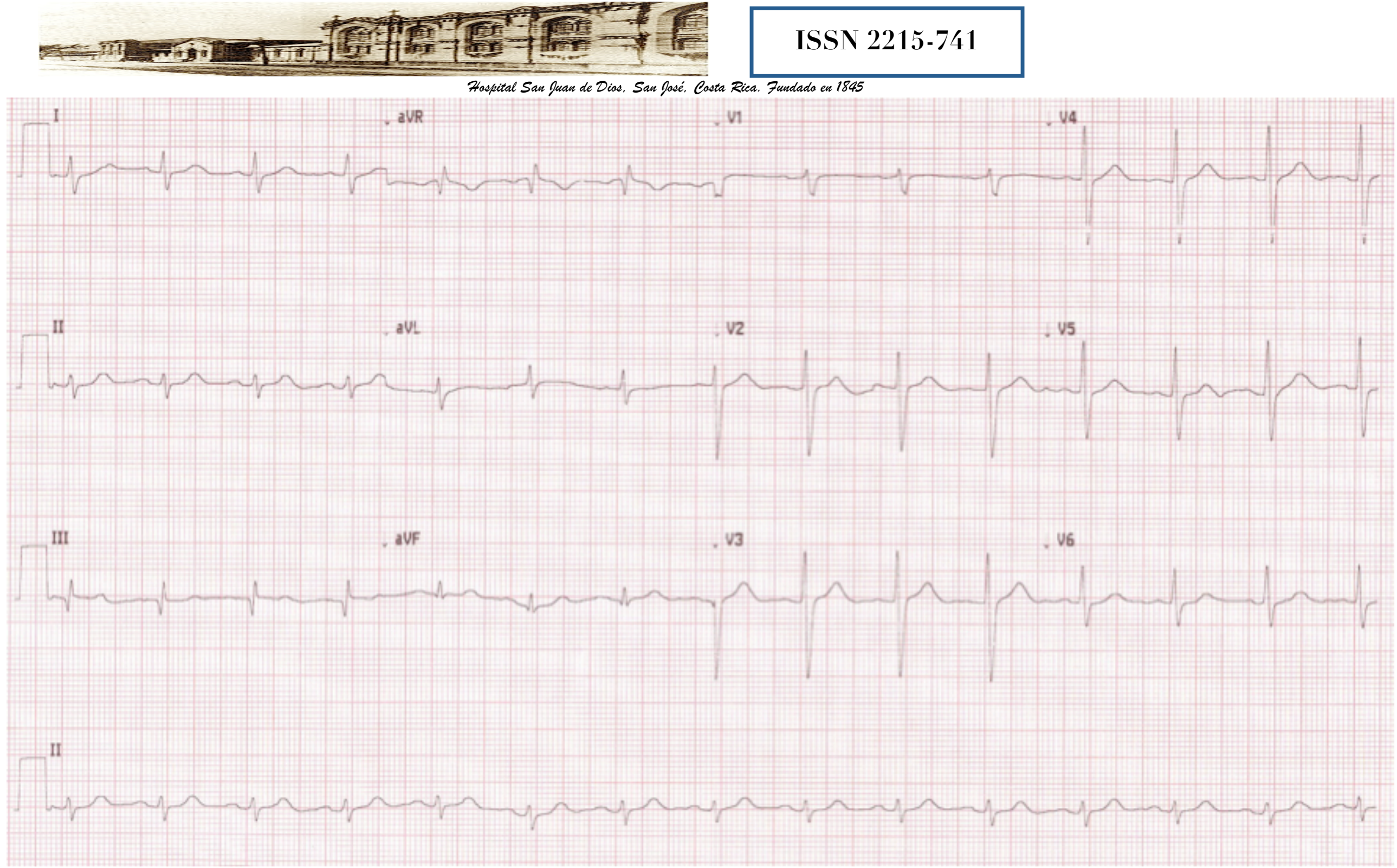